\title{
The San Blas Pluton: An example of Carboniferous plutonism in the Sierras Pampeanas, Argentina
}

\author{
J.A. Dahlquist ${ }^{\text {a,* }}$, R.J. Pankhurst ${ }^{\mathrm{b}}$, C.W. Rapela ${ }^{\mathrm{c}}$, C. Casquet ${ }^{\mathrm{d}}$, \\ C.M. Fanning ${ }^{\text {e }}$, P. Alasino ${ }^{\text {f }}$, M. Baez ${ }^{\mathrm{g}}$ \\ ${ }^{a}$ UNdeC-CRILAR-CONICET, Entre Ríos y Mendoza, 5301 Anillaco, La Rioja, Argentina \\ ${ }^{\mathrm{b}}$ NERC Isotope Geosciences Laboratory, British Geological Survey, Keyworth, Nottingham, NG12 5GG, UK \\ ${ }^{\mathrm{c}}$ Centro de Investigaciones Geológicas, Universidad Nacional de La Plata-CONICET, Calle 1 No. 644, 1900 La Plata, Argentina \\ ${ }^{\mathrm{d}}$ Universidad Complutense de Madrid, Facultad de Geología, Dpto. de Petrología y Geoquímica, 28040 Madrid, España \\ ${ }^{\mathrm{e}}$ Research School of Earth Sciences, The Australian National University, Mills Road, Canberra, ACT 0200, Australia \\ ${ }^{\mathrm{f}}$ CRILAR-CONICET, Entre Ríos y Mendoza, 5301 Anillaco, La Rioja, Argentina \\ ${ }^{\mathrm{g}}$ INSUGEO-UNT, Miguel Lillo 205, 4000 S.M. de Tucumán, Argentina
}

\begin{abstract}
New geochronological and geochemical data are reported for the San Blas Pluton (SBP), in the northwestern Sierra de Velasco, Sierras Pampeanas, which intrudes Ordovician granitoids developed during the Famatinian orogeny. A precise Carboniferous age of $340 \pm 3$ Ma is established by U-Pb dating of zircon using a sensitive high-resolution ion microprobe (SHRIMP). The SBP illustrates several petrological and geochemical characteristics of previously reported Carboniferous granitoids in the Sierras Pampeanas. Their generation is consistent with a regional reheating of the crust at approximately $342 \mathrm{Ma}$, which resulted in the formation of relatively large amounts of granitic melts that were emplaced in higher crustal levels along master fractures (older master shear zones of Lower Paleozoic age). The SBP can be chemically defined as a typical A-type granitoid related to postcollisonal or postorogenic magmatism. Its high REE content and extraordinarily high U and Th concentrations may have economic significance. Many previously published Devonian and Carboniferous K-Ar dates are reset Ordovician ages, but the existence of other Carboniferous bodies in the Sierra de Velasco cannot be discounted until detailed mapping of the whole Sierra is completed.
\end{abstract}

Keywords: SHRIMP; San Blas Pluton; Sierra de Velasco; Carboniferous age; A-type granitoids; Postorogenic magmatism

\section{Introduction}

Located in NW Argentina, the Sierras Pampeanas are a series of mountainous ranges, comprising crystalline basement intruded by diverse Paleozoic igneous rocks, which were elevated during Miocene to recent compressional (Andean) tectonics (e.g. Jordan and Allmendiger, 1986) (Fig. 1). The igneous rocks were generated in three main orogenic events: (a) Pampean (latest Neoproterozoic-mid Cambrian), (b) Famatinian (early-mid Ordovician), and (c) Achalian (late Devonian-early Carboniferous) (Pankhurst et al., 1998; Rapela et al., 1998a,b; Sims et al., 1998; Dahlquist et al., 2005). This study focuses on granitoid outcrops in the northwest of the

\footnotetext{
* Corresponding author.
}

Sierra de Velasco, which is located in the central part of the Sierras Pampeanas (Fig. 1). Most granitoids in the Sierra de Velasco were emplaced in early Ordovician times during the Famatinian orogeny, which took place along the proto-Andean margin of Gondwana. Extensive literature on the Famatinian orogen is reported by Pankhurst et al. $(1998,2000)$, Rapela et al. (1998b, 2001a), Sims et al. (1998), Dahlquist and Galindo (2004), and Dahlquist et al. (2005) (and references therein). In this article, we present new SHRIMP U-Pb zircon data and geochemistry that confirm the presence of Carboniferous magmatism, in this case represented by the San Blas Pluton (SBP) (Fig. 1). Following Sims et al.'s (1998) definition, we use the name Achalian granites for the products of this Devonian-Carboniferous magmatism and discuss regional implications for the development of the proto-Andean margin at this latitude.

The Carboniferous granites are dominated by hornblendebiotite and biotite porphyritic monzogranites, sometimes 


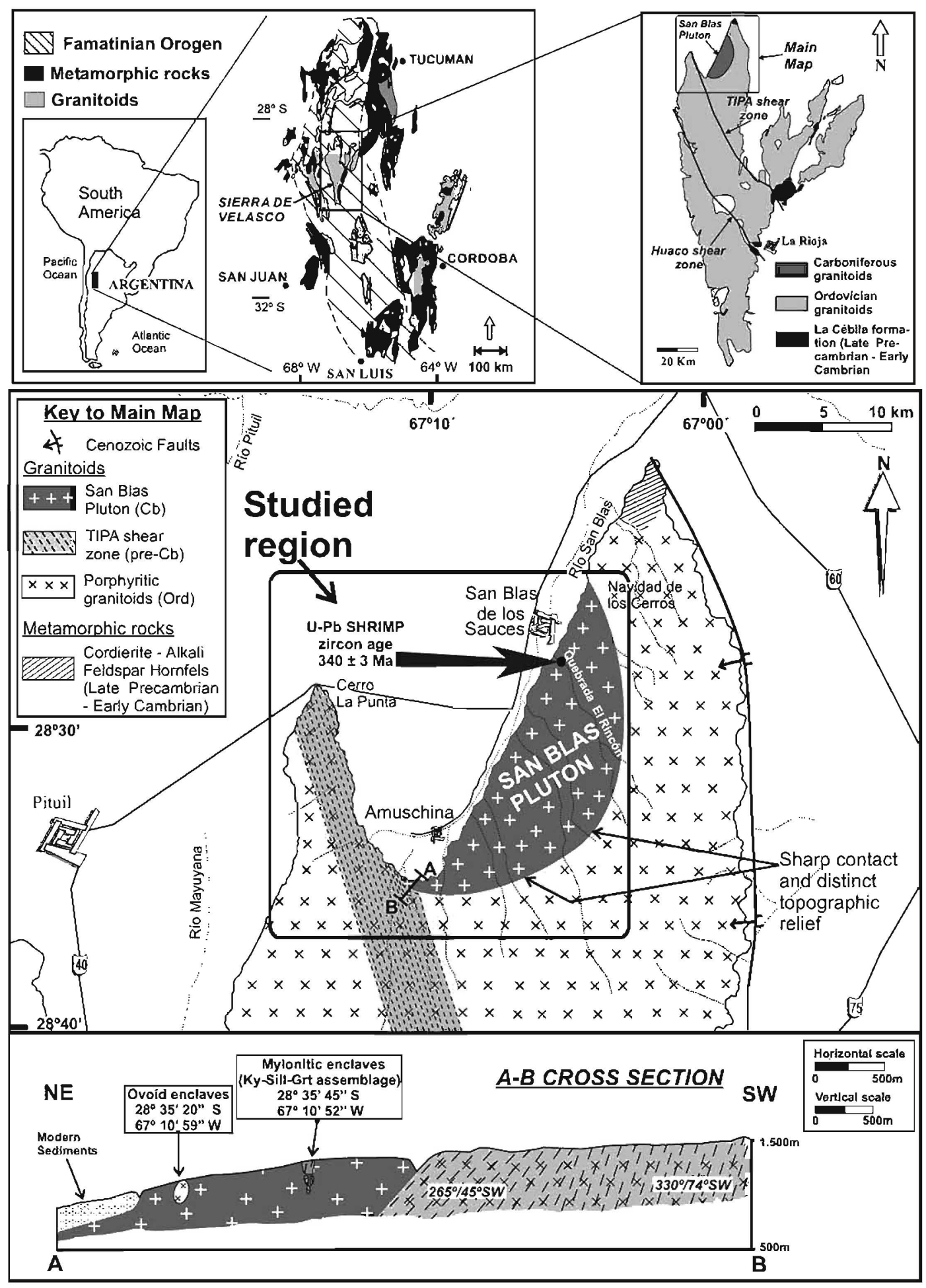

Fig. 1. Simplified sketch map of Sierras Pampeanas (top left), Sierra de Velasco (top right), and study area (bottom). Sierra de Velasco is located in the Famatinian magmatic arc (early-mid Ordovician).

defining a trend from quartz monzonite to syenogranitic facies (Rapela et al., 1992). Pegmatites, aplites, and, in some cases, quartz porphyries and rhyolites are related to the plutons. The geochemical characteristics of the Carboniferous granites are typical of those found in intracratonic settings, and they primarily plot in or near the within-plate field in tectonic discrimination diagrams (Rapela et al., 1992). The isotopic characteristics of these granites have not been studied systematically, though some ${ }^{87} \mathrm{Sr} /{ }^{86} \mathrm{Sr}$ data indicate a significant crustal component in the source. Despite their potential economic significance, in that they are associated with $U$ and REE mineralization (e.g. Lira and Ripley, 1989; Grissom, 1991; Saavedra et al., 1998), few detailed studies have been carried out on these granites. 


\section{Geology of the Sierra de Velasco}

The Sierra de Velasco, located in the central part of the Famatinian belt (Rapela, 2000), is dominated by Paleozoic granitic rocks and subordinate late Precambrian-Cambrian (?) low-grade metamorphic rocks (Fig. 1). This basement is unconformably overlain by minor remnants of middle-late Carboniferous to Permian continental sediments formed during regional uplift of the Sierras Pampeanas (e.g. the Paganzo Group) and locally by tertiary-recent continental basin sediments related to Andean tectonics.

Aceñolaza et al. (2000) give a general description of the main units of the basement, which is adapted here according to recent geological, petrographical, and geochronological results reported by Pankhurst et al. (2000), Toselli et al. (2000), Alasino (2002), Baez et al. (2002), and Höckenreiner et al. (2003). The metamorphic rocks on the eastern flank of the Sierra de Velasco are phyllites, quartzites, and mica schists correlated with similar lithologies of the La Cébila Formation in Sierra de Ambato (Aceñolaza et al., 2000). On the western flank, metasedimentary migmatites of unknown age are found as large enclaves within the granites.

The most abundant rocks in the Sierra de Velasco are granitoids assigned to the Ordovician period (Fig. 1). The most common varieties are as follows: (1) porphyritic biotite and biotite-muscovite monzogranite to syenogranite, with large microcline megacrysts; (2) coarse- to medium-grained biotite and biotite-muscovite granodiorite to monzogranite; and (3) coarse-grained cordierite and cordierite-garnet monzogranite, so far identified in the sectors of Sierra de Mazán (Toselli et al., 1991) and Pampa de la Viuda (Pankhurst et al., 2000). The main granitoids are the type 1 varieties. All the granitic varieties are foliated. In different places, the granitoids reveal superimposed mylonitic foliation (e.g. Rapela et al., 2001b; Höckenreiner et al., 2003). In the studied region, mylonitic rocks of the Tinogasta-Pituil-Antinaco (TIPA) shear zone (López and Toselli, 1993; Höckenreiner et al., 2003) are observed (Fig. 1).

\subsection{Petrological characteristic of the San Blas Pluton}

The SBP (Baez et al., 2002) is a semi-ellipsoidal intrusive body of approximately $100 \mathrm{~km}^{2}$ located in the northwestern part of Sierra de Velasco (Fig. 1). The host rocks are Famatinian granitoids and mylonitic rocks of the TIPA shear zone (according to the nomenclature of Höckenreiner et al., 2003). The contact of the SBP with the surrounding Famatinian granitoids is sharp and marked by a strong topographic relief. Moreover, the SBP lacks the penetrative mylonitic deformation of the TIPA shear zone, which is also widely found in the porphyritic granitoids of Sierra de Velasco (regional distribution of mylonites from Aceñolaza et al., 2000; Höckenreiner et al., 2003; Fig. 1).

The dominant rock types in the SBP are porphyritic, biotite monzogranite to syenogranite in composition with accessory muscovite. Their petrography is characterized by large microcline crystals (3-15 cm long), which constitute 6-35\% of the mode. The matrix is medium grained, equigranular, and formed mainly by quartz, microcline, albite, and biotite. Miariolitic textures have been observed. Baez et al. (2002) and Alasino (2002) recognize three additional facies, though their extent has not yet been determined for the area of the pluton, and in some places, they are limited to meter-scale blocks. These facies are as follows: (1) a common, slightly foliated porphyritic facies similar to the porphyritic granitoids of Sierra de Velasco (Alasino, 2002); (2) a medium- to coarse-grained equigranular facies; and (3) a 'granitic porphyry' facies, which is distinguished from the main facies by its fine-grained matrix. Felsic and mafic dykes cut the granites. Mafic microgranular enclaves have also been recognized (Baez et al., 2002), mainly in the northern region of the SBP (e.g. Navidad de los Cerros, Fig. 1). A fabric defined by the alignment of microcline phenocrysts is developed close to the margin of SBP and interpreted as magmatic in origin (Alasino, 2002).

\subsection{Previous evidence for late emplacement of the $S B P$}

Baez et al. (2002) conclude that the presence of mylonitic rocks (ascribed to the TIPA shear zone of Höckenreiner et al., 2003) as enclaves within the SBP and undeformed pegmatite dykes discordant to the regional fabric of the mylonites indicate postdeformational emplacement of the SBP. The age of the deformational event in Sierra de Velasco was estimated as $469 \pm 3$ Ma by Rapela et al. (2001b). Similarly, Alasino (2002) presents several arguments that the SBP does not belong to the early Paleozoic magmatism of the Famatinian orogeny, which pertain to:

1. The discordant relationship between the SBP and a host mylonite (TIPA shear zone) in the southwestern part of the outcrop. Remarkably, the mylonitic foliation trends almost $\mathrm{E}-\mathrm{W}\left(265^{\circ}\right)$ in the contact zone, compared with its regional trend of $340^{\circ}$ (Fig. 1).

2. Mylonitic enclaves (with kyanite-garnet-sillimanite assemblages), equivalent to the rocks of the TIPA shear zone outcrop in the Cerro la Punta (Rossi et al., 1999) (Fig. 1), present in the SBP.

3. Deformation conditions for mylonitic rocks of the TIPA shear zone estimated in the range of 6.5-8 kbar (Rossi et al., 1999), very different from the shallow emplacement of the SBP (Baez et al., 2002).

4. Ovoid enclaves (meter-scale) in the SBP similar to porphyritic Ordovician granitoids of the Sierra de Velasco. These granitic enclaves have an internal foliation, unlike the host SBP. Our own observations confirm sharp contacts and are consistent with the idea that the granitic porphyry facies represents large enclaves of the Ordovician granitoids included in the main facies of the SBP.

Thus, there is good field evidence of the intrusion of the SBP significantly later than the emplacement and deformation of the Ordovician porphyritic granitoids of Sierra de Velasco, probably after they had undergone significant uplift. 


\subsection{General geochemistry characteristics}

A sample of the porphyritic facies (VEL-6017) was taken from the outcrops at the NW end of Quebrada del Rincón (Fig. 1); we present its geochemistry in Table 1. Major element geochemistry indicates that VEL-6017 is metaluminous (aluminum saturation index $<1.0$ ) and can be chemically defined as an A-type granitoid, in agreement with Whalen et al. (1987), Eby (1990), and Scheepers (2000), displaying high total alkalis (8.56\%), high $\mathrm{Fe}_{2} \mathrm{O}_{3}^{\text {total }} / \mathrm{MgO}$ (45.75) ratios, and low $\mathrm{CaO}, \mathrm{Sr}$, and $\mathrm{P}_{2} \mathrm{O}_{5}$ contents. It is also silica rich. Its trace element geochemistry reveals an A-type granite signature with a remarkable enrichment in high field strength (HFS) elements such as $\mathrm{Y}(78 \mathrm{ppm}), \mathrm{Nb}(51 \mathrm{ppm}), \mathrm{Ta}(7.7 \mathrm{ppm}), \mathrm{REE}_{\text {total }}$

Table 1

Chemical analyses for VEL-6017 from San Blas Pluton (SBP), Sierra de Velasco

\begin{tabular}{|c|c|}
\hline Sample & SBP porphyritic facies VEL- 6017 \\
\hline \multicolumn{2}{|c|}{ Major oxides (wt.\%) } \\
\hline $\mathrm{SiO}_{2}$ & 75.75 \\
\hline $\mathrm{TiO}_{2}$ & 0.11 \\
\hline $\mathrm{Al}_{2} \mathrm{O}_{3}$ & 12.50 \\
\hline $\mathrm{Fe}_{2} \mathrm{O}_{3}^{\mathrm{t}}$ & 1.83 \\
\hline $\mathrm{MnO}$ & 0.03 \\
\hline $\mathrm{MgO}$ & 0.04 \\
\hline $\mathrm{CaO}$ & 0.72 \\
\hline $\mathrm{Na}_{2} \mathrm{O}$ & 3.38 \\
\hline $\mathrm{K}_{2} \mathrm{O}$ & 5.18 \\
\hline $\mathrm{P}_{2} \mathrm{O}_{5}$ & 0.03 \\
\hline LOI & 0.42 \\
\hline Total & 99.99 \\
\hline \multicolumn{2}{|c|}{ Trace elements (ppm) } \\
\hline Cs & 22.7 \\
\hline $\mathrm{Rb}$ & 573 \\
\hline $\mathrm{Sr}$ & 22 \\
\hline $\mathrm{Ba}$ & 104 \\
\hline $\mathrm{La}$ & 66.8 \\
\hline $\mathrm{Ce}$ & 146 \\
\hline Pr & 16.4 \\
\hline $\mathrm{Nd}$ & 58.7 \\
\hline $\mathrm{Sm}$ & 13.1 \\
\hline $\mathrm{Eu}$ & 0.602 \\
\hline $\mathrm{Gd}$ & 11.7 \\
\hline $\mathrm{Tb}$ & 2.34 \\
\hline Dy & 13.5 \\
\hline Ho & 2.82 \\
\hline $\mathrm{Er}$ & 8.67 \\
\hline $\operatorname{Tm}$ & 1.34 \\
\hline $\mathrm{Yb}$ & 8.69 \\
\hline $\mathrm{Lu}$ & 1.23 \\
\hline $\mathrm{U}$ & 12.7 \\
\hline Th & 71.5 \\
\hline Y & 78.1 \\
\hline $\mathrm{Nb}$ & 51 \\
\hline $\mathrm{Zr}$ & 207 \\
\hline Hf & 8.2 \\
\hline Та & 7.65 \\
\hline $\mathrm{Ga}$ & 28.00 \\
\hline $\mathrm{Ge}$ & 2.80 \\
\hline
\end{tabular}

Whole-rock major and trace elements were determined using ICP and ICP-MS, respectively, at Activation Laboratories, Ontario, Canada (ACTLABs). Total iron as $\mathrm{Fe}_{2} \mathrm{O}_{3}$.
(352 ppm), Th (72 ppm), U (13 ppm), and Ga (28 ppm). VEL6017 also shows enrichment in certain large-ion lithophile (LIL) elements, such as $\mathrm{K}$ and $\mathrm{Rb}$. The $\mathrm{Zr}$ concentration ( $207 \mathrm{ppm})$ is normal for metaluminous granitic rocks. Multielement diagrams using data from Table 1 (plots not shown here) indicate an upper crustal signature, and REE patterns suggest fractionation of plagioclase without garnet, in agreement with the deductions of Toselli et al. (2000). According to geochemical discrimination parameters defined by Eby (1992), the sample is a postcollisional or postorogenic granitoid (type- $\mathrm{A}_{2}$ of Eby, 1992), emplaced at the end of a long period of high heat flow and granitic magmatism. The combined $\mathrm{Th}+\mathrm{U}$ content of $84.20(\mathrm{Th} / \mathrm{U}=5.63)$ is much higher than the Clarke value of $21 \mathrm{ppm}$ for granitic rocks (Scheepers, 2000), characterizing granitoids of the SBP as radio element-enriched. Thus, the high REE and very high $\mathrm{U}$ and Th concentrations may have potential economic significance.

The isotopic characteristics of these granites have not been studied systematically; we have no new data for the SBP, but two samples analyzed by Rapela et al. (1982) yield initial ${ }^{87} \mathrm{Sr} /{ }^{86} \mathrm{Sr}$ ratios of 0.7088 , using the age, determined here, of $340 \mathrm{Ma}$. This ratio is indistinguishable from the initial ${ }^{87} \mathrm{Sr} /{ }^{86} \mathrm{Sr}$ ratio of 0.7086 given by a $337 \mathrm{Ma}$ whole-rock isochron for the Capilla del Monte granite, Sierras de Córdoba (Saavedra et al., 1998) and implies a common homogeneous source region with a significant crustal component. The composition of VEL-6017 is very similar to those of granitoids in the Sierra de Zapata of Carboniferous age, which have been interpreted as the last phase of within-plate magmatism (Rapela et al., 1996). Based on these characteristics, VEL6017 can be distinguished chemically from the calc-alkaline granitoids of Ordovician age generated during the Famatinian Orogeny (see Pankhurst et al., 1998; Dahlquist, 2000; Dahlquist et al., 2005, and references therein).

\section{Previous geochronology}

The first geochronological results for the granitic rocks of the Sierra de Velasco were part of a regional $\mathrm{K}$ - $\mathrm{Ar}$ age study in the Sierras Pampeanas carried out by Linares and González (1990). Their results from 46 widespread localities in granitic rocks of Sierra de Velasco suggest two periods of plutonism: at 330-340 Ma (early Carboniferous) and 440-450 Ma (late Ordovician). The oldest ages obtained (475-479 Ma, early Ordovician) are from the Sierra de Mazán (Fig. 3), the northeastern branch of the Sierra de Velasco. Two samples were dated from different areas of the SBP described herein ( $332 \pm 16 \mathrm{Ma}$, whole rock; $328 \pm 10 \mathrm{Ma}$, muscovite). Recently, U-Pb SHRIMP dating of granitic rocks from Sierra of Velasco and Mazán, including the cordierite-bearing facies of Pampa de la Viuda, has indicated a closely constrained early Ordovician crystallization age for several facies of the porphyritic Ordovician granitoids of the Sierra de Velasco (484.2 \pm

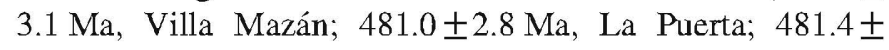
2.4 Ma, Pampa de la Viuda; Pankhurst et al., 2000; Rapela et al., 2001b). Furthermore, analyses of distinct low-U zircon 
overgrowths in the cordierite-bearing granite suggest that a high-temperature metamorphic event overprinted these rocks at $469.0 \pm 3.9 \mathrm{Ma}$ (Rapela et al., 2001b). This event is younger than that magmatic age of $481 \pm 2.4 \mathrm{Ma}$ shown by these granitoids (Rapela et al., 2001b). However, the Sm-Nd garnet analyses in neighboring areas of the prominent NNW-SSEtrending TIPA shear zone have yielded an early Devonian age (402.0 \pm 2.0 Ma, Höckenreiner et al., 2003).

\section{New SHRIMP U-Pb zircon age}

Zircons were separated from sample VEL-6017 at NERC Isotope Geosciences Laboratory, $\mathrm{UK}$, and analyzed for $\mathrm{U}-\mathrm{Pb}$ isotopic composition using SHRIMP RG at the Australian National University, Canberra (Williams, 1998). Photographic and cathodoluminescence images (Fig. 2) show that they are moderately euhedral platy needles, with outer concentric zonation on complex inner cores and occasionally with a thin outermost rim of luminescent (low-U) zircon. The igneous crystallization of the granitoid is considered represented by the concentric zonation, best developed in the tips of long crystals, which were targeted for analysis. Nineteen such analyses were carried out (Table 2) and are plotted in a Tera-Wasserburg diagram (Fig. 2). Following standard practice for young ages dated by SHRIMP, we calculated ${ }^{238} \mathrm{U} /{ }^{206} \mathrm{~Pb}$ ages after correcting for common $\mathrm{Pb}$ on the basis of the measured ${ }^{207} \mathrm{~Pb}$. Two analyses with large errors appear to have suffered $\mathrm{Pb}$-loss, and the oldest one, at $355 \pm 4 \mathrm{Ma}$, may contain a slight inheritance, as indicated by the cores. No such problems are apparent for the remaining 16 ages, which give a well-defined mean of $340 \pm 3 \mathrm{Ma}$. This age is taken to refer to crystallization, dating the emplacement of the SBP in the Visean stage (or possibly very latest Tournaisian) of the Carboniferous period, according to the 2002 IUGS stratigraphic chart. It clearly represents a separate, much younger event than the mid Ordovician granitoids of the Velasco batholith.

\section{Discussion}

\subsection{Composition of the Devonian-Carboniferous granites}

Three main granitoid groups have been recognized in the Eastern Sierras Pampeanas using chronological criteria and through association with major orogenic episodes (Rapela et al., 1990). This classification, modified slightly, has been extended to Paleozoic granites in other geological provinces of southern South America (Rapela et al., 1992; Rapela and Llambías, 1999; Pankhurst et al., 2000) with the following designations: $\mathrm{G} 1=$ Precambrian-middle Cambrian granites (Pampean), G2 = late Cambrian-Devonian granites (Famatinian), and G3=Devonian-Carboniferous granites.

The large amount of geochronological data on the Pampean and Famatinian granites reported during the past 10 years has improved our knowledge of the timing of these groups, but the late Paleozoic granites emplaced after the metamorphic peak of the Famatinian orogeny have received relatively little attention. Sims et al. (1998) consider the voluminous Devonian intrusive rocks in Sierras de Córdoba and eastern Sierras de San Luis associated with Devonian low-grade shear zones, together defining the Achalian orogeny. According to this interpretation, these Devonian granites, such as the Achala and Cerro Aspero batholiths (e.g. Pinotti et al., 2002), are not postorogenic intrusions of the Famatinian orogeny, as suggested by Rapela et al. (1998b), but belong to a distinct tectonomagmatic event. In NW Argentina, this episode produced extensive NNW-SSE-trending ductile shear zones that reached amphibolite grade, including the TIPA shear zone (Höckenreiner et al., 2003). The Devonian compressional episode also has been related to either collision of the Chilenia terrane with the proto-Pacific margin (Sims et al., 1998) or final collision between the Famatinian magmatic arc and the Pampean hinterland (Höckenreiner et al., 2003). To be consistent with previous associations between the names of the orogenies and those of the associated granitoids, we call the Devonian and Carboniferous granites Achalian granites (Fig. 3).

Carboniferous granites are the youngest representatives of the Achalian orogeny and conclude the Paleozoic magmatic evolution of the Sierras Pampeanas (Fig. 3). This intrusive event preceded late Carboniferous exhumation of deep metamorphic levels and deposition of the continental sediments of the Paganzo Group. In most cases, the Carboniferous granites seem to be shallow-emplaced plutons dominated by facies with K-feldspar megacrysts. They are small, isolated, subcircular plutons scattered through the eastern Sierras Pampeanas without any obvious spatial arrangements. The aggregation of plutons results in bodies of batholitic size, as in Sierra de San Luis (Brogioni, 1987). Carboniferous examples of the Achalian granite group are the Cerro Amarillo granite (Cumbres Calchaquíes, $330 \pm 10 \mathrm{Ma}, \mathrm{K}-\mathrm{Ar}$, Rapela, 1976), Sauce Guacho granite (Sierra de Ancasti, $334 \pm 11 \mathrm{Ma}, \mathrm{Rb}-\mathrm{Sr}$, Knüver, 1983), Los Ratones granite (Sierra de Fiambalá, $335 \mathrm{Ma}, \mathrm{U}-\mathrm{Pb}$ zircon; $325 \mathrm{Ma}, \mathrm{U}-\mathrm{Pb}$ monazite, Grissom et al., 1998), Granito Capilla del Monte (Sierra de Córdoba, 336.6士 2.4 Ma, Rb-Sr, Saavedra et al., 1998), Las Chacras-Piedras Coloradas batholith (Sierra de San Luis, $321 \pm 16$ and $336 \pm$ 17 Ma, K-Ar, Brogioni, 1987; $335 \pm 10$ Ma, Rb-Sr, Brogioni, 1993) (Fig. 3), and Cerro Veladero granite (Sierra de Umango, $311 \pm 15 \mathrm{Ma}, \mathrm{Rb}-\mathrm{Sr}$, Cingolani et al., 1993). In the Achala batholith, though a conventional U-Pb age determination in the central part of the body indicates a Devonian age $(368 \pm 2 \mathrm{Ma}$, Dorais et al., 1997), $\mathrm{Rb}-\mathrm{Sr}$ isochrons in the northeastern margin of the batholith suggest a Carboniferous age (337 \pm 30 ; $358 \pm 9 \mathrm{Ma}$, Rapela et al., 1991). Despite the variety of dating methods employed, most of these ages are constrained to the 330-340 Ma interval (early Carboniferous), indicating a rapid and voluminous magmatic pulse.

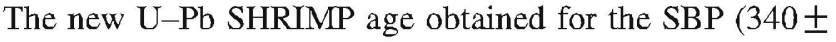
$3 \mathrm{Ma}$, Fig. 2) is more precise than any previous ages obtained in the Carboniferous group and similar to the $342.2 \pm 1.8 \mathrm{Ma}$ age for apatite from metagranodiorites associated with the TIPA shear zone, which is believed to represent peak metamorphic conditions during a crustal heating process (Höckenreiner et al., 2003). It is also coincident with $\mathrm{K}-\mathrm{Ar}$ 


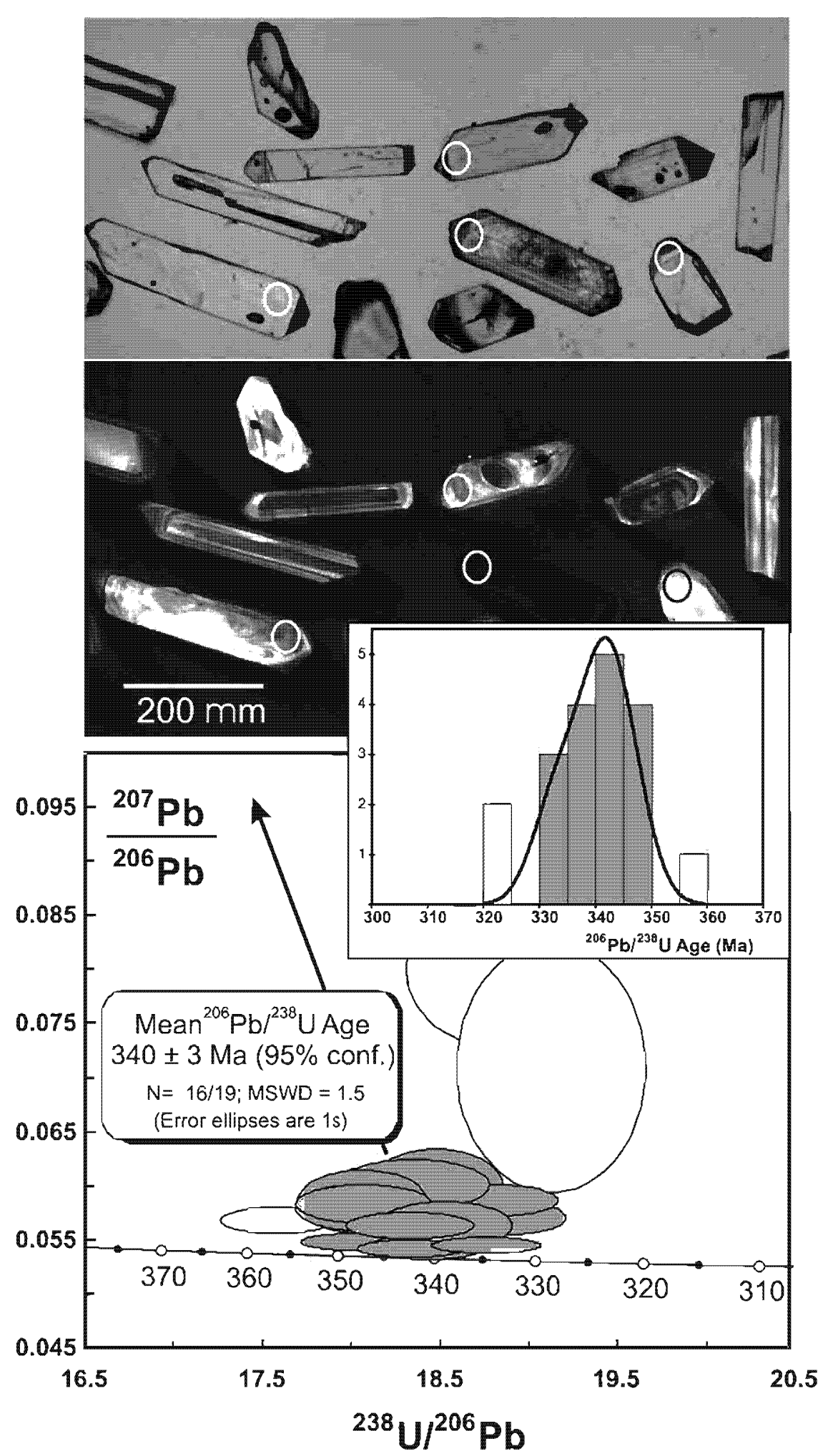

Fig. 2. Illustrative details of the U-Pb zircon dating of VEL-6017. (Top) Photomicrograph of acicular zircon grains showing analyzed areas. (Middle) Cathodoluminescence image of the same grains. (Bottom) Tera-Wasserburg plot with (inset) relative probability plot for ${ }^{238} \mathrm{U}-{ }^{206} \mathrm{~Pb}$ ages after correction for common $\mathrm{Pb}$ using measure ${ }^{207} \mathrm{~Pb}$. The arrow shows the direction for mixing with common $\mathrm{Pb}$ at $340 \mathrm{Ma}$.

ages from Sierra de Velasco (Linares and González, 1990). U$\mathrm{Pb}$ ages indicate that large sectors of Sierra de Velasco are dominated by early Ordovician 'Famatinian' granitoids (Pankhurst et al., 2000). The granitic protoliths of the mylonites supported by the Famatinian granitoids also probably were Ordovician, as demonstrated in the neighboring mylonitic areas of Sierras de Copacabana and Fiambalá (Höckenreiner et al., 2003) (Fig. 3). Some Devonian and 
Table 2

Summary of SHRIMP U-Pb zircon results for sample VEL 6017

\begin{tabular}{|c|c|c|c|c|c|c|c|c|c|c|c|c|c|c|}
\hline \multirow[t]{2}{*}{ Grain spot } & \multirow[t]{2}{*}{$\mathrm{U}(\mathrm{ppm})$} & \multirow[t]{2}{*}{ Th (ppm) } & \multirow[t]{2}{*}{$\mathrm{Th} / \mathrm{U}$} & \multirow{2}{*}{$\begin{array}{l}{ }^{206} \mathrm{~Pb}^{*} \\
(\mathrm{ppm})\end{array}$} & \multirow[t]{2}{*}{${ }^{204} \mathrm{~Pb} /{ }^{206} \mathrm{~Pb}$} & \multirow{2}{*}{$\mathrm{f}_{206 \%}$} & \multicolumn{4}{|l|}{ Total } & \multicolumn{3}{|l|}{ Radiogenic } & \multirow{2}{*}{$\begin{array}{l}\text { Age (Ma) } \\
\pm\end{array}$} \\
\hline & & & & & & & ${ }^{238} \mathrm{U} /{ }^{206} \mathrm{~Pb}$ & \pm & ${ }^{207} \mathrm{~Pb} /{ }^{206} \mathrm{~Pb}$ & \pm & ${ }^{206} \mathrm{~Pb} / /^{238} \mathrm{U}$ & \pm & ${ }^{206} \mathrm{~Pb} /{ }^{238} \mathrm{U}$ & \\
\hline 1.1 & 404 & 211 & 0.52 & 18.4 & 0.000317 & 0.49 & 18.878 & 0.219 & 0.0570 & 0.0011 & 0.0527 & 0.0006 & 331.1 & 3.8 \\
\hline 2.1 & 321 & 241 & 0.75 & 15.7 & 0.000045 & 0.39 & 17.594 & 0.209 & 0.0568 & 0.0008 & 0.0566 & 0.0007 & 355.0 & 4.2 \\
\hline 3.1 & 156 & 72 & 0.46 & 7.2 & 0.000413 & 0.84 & 18.487 & 0.246 & 0.0600 & 0.0022 & 0.0536 & 0.0007 & 336.8 & 4.5 \\
\hline 4.1 & 251 & 119 & 0.47 & 11.5 & 0.000359 & 0.69 & 18.805 & 0.235 & 0.0586 & 0.0010 & 0.0528 & 0.0007 & 331.8 & 4.1 \\
\hline 5.1 & 277 & 130 & 0.47 & 12.9 & -0.000005 & 0.43 & 18.365 & 0.225 & 0.0568 & 0.0014 & 0.0542 & 0.0007 & 340.3 & 4.1 \\
\hline 6.1 & 97 & 48 & 0.50 & 4.6 & 0.000738 & 0.85 & 18.358 & 0.282 & 0.0601 & 0.0016 & 0.0540 & 0.0008 & 339.1 & 5.2 \\
\hline 7.1 & 310 & 141 & 0.46 & 14.5 & 0.000240 & 0.23 & 18.302 & 0.218 & 0.0552 & 0.0011 & 0.0545 & 0.0007 & 342.2 & 4.0 \\
\hline 8.1 & 167 & 166 & 1.00 & 7.9 & 0.000347 & 0.63 & 18.072 & 0.243 & 0.0584 & 0.0020 & 0.0550 & 0.0008 & 345.1 & 4.6 \\
\hline 9.1 & 192 & 93 & 0.48 & 9.2 & 0.000381 & 0.56 & 18.049 & 0.230 & 0.0579 & 0.0014 & 0.0551 & 0.0007 & 345.7 & 4.4 \\
\hline 10.1 & 3121 & 689 & 0.22 & 147.1 & 0.000054 & 0.12 & 18.231 & 0.187 & 0.0543 & 0.0003 & 0.0548 & 0.0006 & 343.8 & 3.5 \\
\hline 11.1 & 79 & 113 & 1.43 & 3.6 & 0.002202 & 3.39 & 18.799 & 0.318 & 0.0801 & 0.0047 & 0.0514 & 0.0010 & 323.1 & 5.9 \\
\hline 12.1 & 735 & 357 & 0.49 & 35.0 & 0.000153 & 0.16 & 18.028 & 0.197 & 0.0547 & 0.0005 & 0.0554 & 0.0006 & 347.5 & 3.7 \\
\hline 13.1 & 164 & 87 & 0.53 & 7.8 & 0.000654 & 0.60 & 18.079 & 0.250 & 0.0582 & 0.0011 & 0.0550 & 0.0008 & 345.0 & 4.7 \\
\hline 14.1 & 560 & 252 & 0.45 & 26.1 & 0.000101 & 0.14 & 18.440 & 0.209 & 0.0544 & 0.0008 & 0.0542 & 0.0006 & 340.0 & 3.8 \\
\hline 15.1 & 184 & 79 & 0.43 & 8.5 & 0.000236 & 0.38 & 18.532 & 0.249 & 0.0563 & 0.0015 & 0.0538 & 0.0007 & 337.5 & 4.5 \\
\hline 16.1 & 331 & 144 & 0.44 & 15.5 & 0.000396 & 0.37 & 18.337 & 0.235 & 0.0563 & 0.0008 & 0.0543 & 0.0007 & 341.1 & 4.3 \\
\hline 17.1 & 65 & 35 & 0.54 & 2.9 & 0.002610 & 2.25 & 19.130 & 0.352 & 0.0709 & 0.0077 & 0.0511 & 0.0011 & 321.3 & 6.6 \\
\hline 18.1 & 923 & 351 & 0.38 & 43.2 & 0.000107 & 0.10 & 18.344 & 0.196 & 0.0541 & 0.0005 & 0.0545 & 0.0006 & 341.8 & 3.6 \\
\hline 19.1 & 903 & 373 & 0.41 & 41.4 & 0.000068 & 0.16 & 18.765 & 0.201 & 0.0544 & 0.0005 & 0.0532 & 0.0006 & 334.2 & 3.5 \\
\hline
\end{tabular}

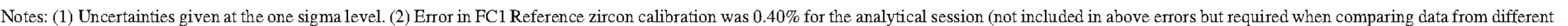

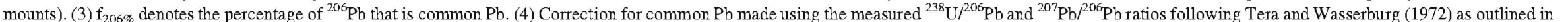
Compston et al. (1992). (5) Italic type indicates data not used in overall age calculations. 


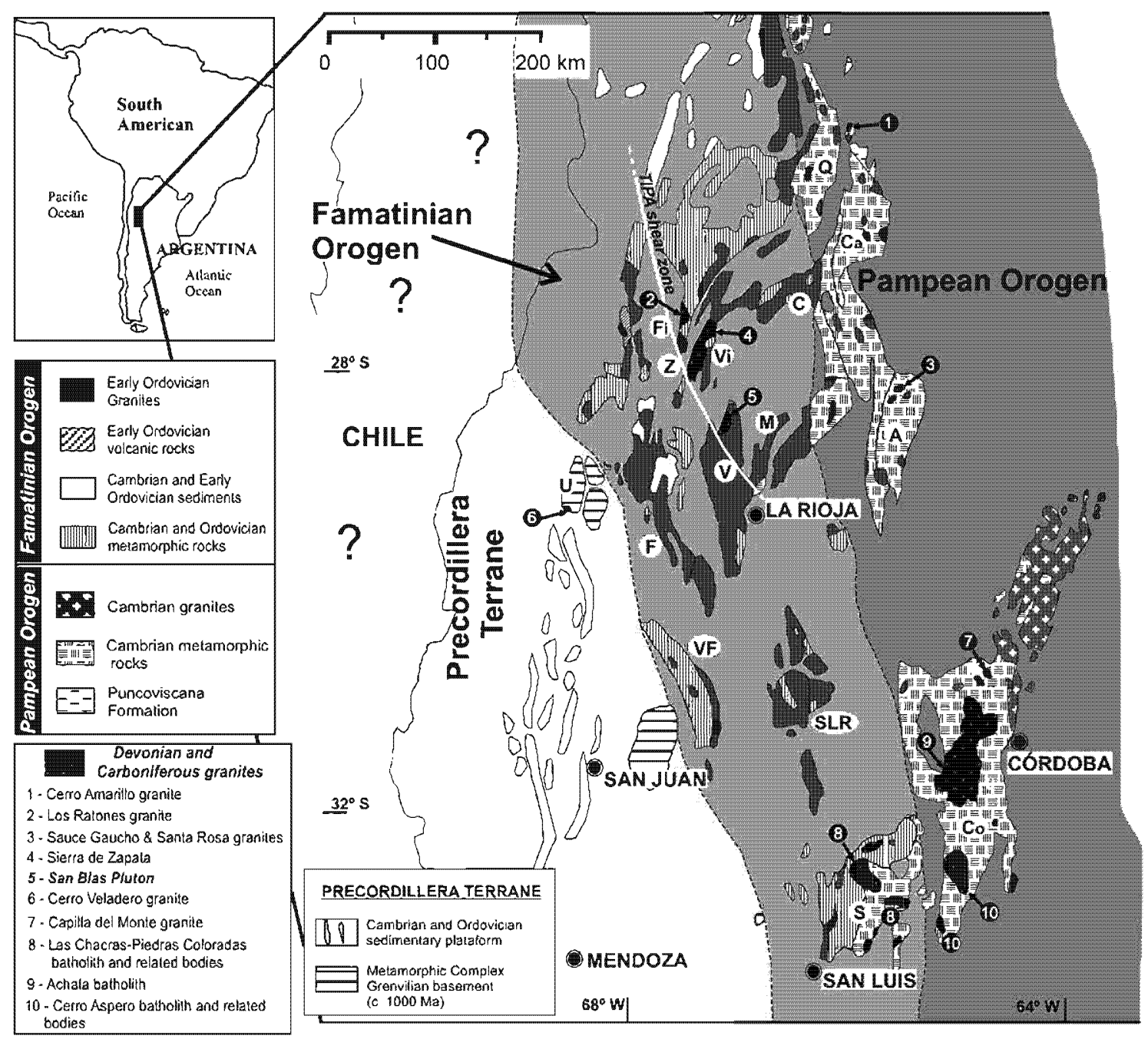

Fig. 3. Generalized sketch map of the Devonian and Carboniferous granites from the Sierras Pampeanas. Letters identify the main localities referred to in the text: (Q) Quilmes, (Ca) Calchaquíes, (C) Capillitas, (Fi) Fiambalá, (Z) Zapata, (Vi) Vinquis, (A) Ancasti, (V) Velasco, (M) Mazán, (F) Famatina, (U) Umango, (VF) Valle Fértil, (SLR) southem La Rioja (including Los Llanos, Chepes, and Ulapes), (Co) Córdoba, and (S) San Luis.

Carboniferous $\mathrm{K}-$ Ar dates may be reset Ordovician ages, but the existence of other Carboniferous bodies in Sierra de Velasco cannot be discounted until detailed mapping and dating of the whole Sierra is completed.

The SBP illustrates several petrological characteristics of the Achalian granites group: (1) dominant biotite porphyritic monzogranite to syenogranite composition, (2) discordant field relationships, (3) nearly circular geometry, (4) relative lithological homogeneity with dominant porphyritic texture (large K-feldspar crystals), (5) shallow emplacement in master fracture zones developed in an extensional tectonic regimen, and (6) the presence of pegmatites, aplites, and granitic dykes. The geochemical data for our sample of the SBP show remarkable similarity to those reported for the granitoids of Sierra de Zapata (see Section 2.3). Thus, the SBP could represent a prolongation of Sierra de Zapata granite magmatism. Remarkably and contrary to the ideas of Höckenreiner et al. (2003), the Cerro Veladero Carboniferous granite was emplaced to the east of the TIPA shear zone (Fig. 3).

\section{Conclusions}

New SHRIMP U-Pb zircon ages establish the presence of Carboniferous magmatism in Sierra de Velasco, as represented by the SBP. The SBP intrudes Ordovician granitoids developed during the Famatinian orogeny, confirming previous field observations that indicate the later emplacement of the SBP (Alasino, 2002; Baez et al., 2002).

The chemical composition indicates that the SBP is an A-type granitoid related to postcollisional or postorogenic events. It shares several petrological and geochemical characteristics with the Achalian granites group. Similarly, the SBP could be a prolongation of the granites of Sierra de Zapata. The high REE content and extraordinarily high $U$ and Th concentrations in these granitoids may have economic significance.

The Carboniferous age of the SBP in Sierra de Velasco shows that detailed studies can reveal the presence of unrecognized Achalian granites. The existence of other 
Carboniferous bodies in Sierra de Velasco cannot be discounted until detailed mapping of the whole sierra is completed.

We agree with Höckenreiner et al. (2003) that regional reheating affected the crust of the Sierras Pampeanas during Carboniferous time $(\sim 342 \mathrm{Ma})$, resulting in the formation of relatively large amounts of granitic melts, which were emplaced at higher crustal levels. The source of heat that caused the production of relatively large amounts of granitic melt during the Devonian-Carboniferous remains undetermined. Recently, Höckenreiner et al. (2003) proposed a schematic model in which the heat source comes from the asthenospheric uprise, favored by the break-off of the subducted lithospheric plate (to form a slab-window) in a dominant compressional regime at approximately $402 \mathrm{Ma}$.

According to Höckenreiner et al. (2003), the TIPA shear zone that affects the porphyritic Ordovician granitoids in the northwest of the Sierra de Velasco, but not the SBP (as we indicated in Section 2.2) (Fig. 1), was mainly developed around $402 \mathrm{Ma}$. Thus, the SBP is a late Achalian granite emplaced at shallow levels along old master fracture zones of late-middle Ordovician or early Devonian age, according to Baldo et al. (1999), Rapela et al. (2001b), and Höckenreiner et al. (2003), respectively. Reactivation probably took place during a tectonic event likely related to extensional regime, as has been suggested for other Achalian granitoids (Pinotti et al., 2002). However, this issue remains poorly constrained.

\section{Acknowledgements}

This work was supported by grants PIP CONICET 02082, BTE2001-1486 (España), and IM40 2000 (ANPCyT, Argentina). R.J. Pankhurst acknowledges tenure of a Leverhulme Trust Emeritus Fellowship, during which this work was completed. J.A. Dahlquist acknowledges Dr H. Levato (CONICET), Engineer Tulio Del Bono (SECyT), and Accountant A. Millon (SECyT).

\section{References}

Aceñolaza, F.G., Miller, H., Toselli, A., 2000. Geología de la Sierra de Velasco, provincia de La Rioja, Argentina. Extended Abstracts-CD-ROM-of the 17 Simposio sobre la geología de Latinoamérica. Profil 18, Institut für Geologie und Paläontologie der Universität Stuttgart, Stuttgart, Germany.

Alasino, P.H., 2002. Caracterización Petrológica del Sector Norte de la Sierra de Velasco, La Rioja, República Argentina. Thesine, CRIAR-UNC, Hemeroteca de la Facultad de Ciencias Exactas, Físicas y Naturales, Universidad Nacional de Córdoba, Argentina, p. 112 (unpublished).

Baez, M.A., Rossi de Toselli, J.N., Sardi, F., 2002. Consideraciones preliminares del norte de la Sierra de Velasco, La Rioja, Argentina. Actas del 15 Congreso Geológico Argentino, CD-ROM, El Calafate.

Baldo, E.G., Saavedra, J., Rapela, C.W., Pankhurst, R.J., Casquet, C.Y., Galindo, C., 1999. Síntesis geocronológica de la evolución paleozoica inferior del borde sur occidental de Gondwana en las Sierras Pampeanas, Argentina. Acta Geológica Hispana 32, 17-28.

Brogioni, N., 1987. El Batolito de Las Chacras-Piedras Coloradas, provincia de San Luis, Geología y edad. 10 Congreso Geológico Argentino, Simposio Granitos Fanerozoicos Circum-Pacíficos Actas, vol. 4, pp. 115-117 (Tucumán).
Brogioni, N., 1993. E1 Batolito de Las Chacras-Piedras Coloradas, provincia de San Luis, Geocronología Rb-Sr y ambiente tectónico. 12 Congreso Geológico Argentino y 2 Congreso de Exploración de Hidrocarburos, Actas, vol. 4, pp. 54-60 (Mendoza).

Cingolani, C., Varela, R., Dalla Salda, L., Kawashita, K., 1993. Los granitoides del Cerro Veladero, Rio de la Troya, provincia de La Rioja: estudio geocronológico e implicancias tectónicas. 12 Congreso Geológico Argentino y 2 Congreso de Exploración de Hidrocarburos Actas, vol. 4, pp. 68-74.

Dahlquist, J.A., 2000. Geología, petrología y geoquímica de las roca de la Sierra de Chepes, La Rioja, Argentina. PhD Thesis, Hemeroteca de la Facultad de Ciencias Exactas, Físicas y Naturales, Universidad Nacional de Córdoba, Argentina, 464 pp. (unpublished).

Dahlquist, J.A., Galindo, C., 2004. Geoquímica isotópica de los granitoides de la sierra de Chepes: un modelo geotectónico y termal, implicancias para el orógeno famatiniano. Revista de la Asociación Geológica Argentina 59 (1), $57-69$.

Dahlquist, J.A., Rapela, C.W., Pankhurst, R.J., Baldo, E., Saavedra, J., Alasino, P.H., 2005. Los granitoides de la sierra de Chepes y su comparación con granitoides paleozoicos de las Sierras Pampeanas: implicancias para el orógeno famatiniano. In: Dahlquist, J.A., Baldo, E.G., Alasino, P.H., (Eds.) Geología de la provincia de La Rioja-Precámbrico-Paleozoico Inferior- Asociación Geológica Argentina, Serie D, Publicación Especial 8, 87-108.

Dorais, M.J., Lira, R., Chen, Y., Tingey, D., 1997. Origin of biotite-apatite-rich enclaves, Achala batholith, Argentina. Contributions to Mineralogy and Petrology 130, 31-46.

Eby, G.N., 1990. The A-type granitoids: a review of their occurrence and chemical characteristics and speculations on their petrogenesis. Lithos 26 , 115-134.

Eby, G.N., 1992. Chemical subdivision of the A-type granitoids: petrogenetic and tectonic implications. Geology 20, 641-644.

Grissom, G.C., 1991. Empirical constraints on thermal processes in he deep crust of magmatic arcs: Sierra de Fiambalá, Northwestem Argentina. $\mathrm{PhD}$ Thesis, Department of Geology, Stanford University, USA (unpublished).

Grissom, G.C., Debari, S.M., Lawrence, W.S., 1998. Geology of the Sierra de Fiambalá, northwestern Argentina: implications for early Palaezoic Andean tectonics. In: Pankhurst, R.J., Rapela, C.W., (Eds.) The Proto-Andean Margin of Gondwana. Geological Society, London, Special Publications $142,297-323$.

Höckenreiner, M., Söllner, F., Miller, H., 2003. Dating the TIPA shear zone: an early Devonian terrane boundary between the Famatinian and Pampean systems (NW Argentina). Joumal of South America Earth Sciences 16, $45-66$.

Jordan, T.E., Allmendiger, R.W., 1986. The Sierras Pampeanas of Argentina: a modem analogue of Rocky mountain foreland deformation. American Journal of Science 286, 737-764.

Knüver, M., 1983. Dataciones radimétricas de rocas plutónicas y metamórficas. In: Aceñolaza, F.G., Miller, H., Toselli, A.J., (Eds.) Geología de la Sierra de Ancasti. Münstersche Forchungen zur Geologie und Paläontologie 59, 372.

Linares, E., González, R.R., 1990. Catálogo de edades radimétricas de la República Argentina (1957-1987). Asociación Geológica Argentina, Publicaciones Especiales, Serie 'B' (Didáctica y Complementaria) 19.

Lira, R., Ripley, E.M., 1989. Fluid inclusión studies of the Rodeo de Los Molles REE and Th deposit, Las Chacras Batholith, Central Argentina. Geochemica et Cosmochimica Acta 54, 663-671.

López, J.P., Toselli, A.J., 1993. La faja milonítica TIPA: faldeo oriental del Sistema de Famatina, Argentina. 12 Congreso Geológico Argentino y 2 Congreso de Exploración de Hidrocarburos Actas, vol. 3, pp. 39-42.

Pankhurst, R.J., Rapela, C.W., Saavedra, J., Baldo, E., Dahlquist, J., Pascua, I., Fanning, C.M., 1998. The famatinian arc in the central Sierras Pampeanas: an early to mid-Ordovician continental arc on the Gondwana margin. In: Pankhurst, R.J., Rapela, C.W., (Eds.) The ProtoAndean Margin of Gondwana, Geological Society of London, Special Publication 142, 343-367.

Pankhurst, R.J., Rapela, C.W., Fanning, C.M., 2000. Age and origin of coeval TTG, I-S-type granites in the Famatinian belt of NW Argentina. Transactions of the Royal Society of Edinburgh, Earth Sciences 91, 151-168. 
Pinotti, L.P., Coniglio, J.E., Esparza, A.M., D'Eramo, F.J., Llambías, E.J., 2002. Nearly circular plutons emplaced by stoping at shallow crustal levels, Cerro Áspero batholith, Sierras Pampenas de Córdoba, Argentina. Journal of South American Earth Sciences 15, 251-265.

Rapela, C.W., 1976. Las rocas graníticas de la región de Cafayate, provincia de Salta. Aspectos petrlógicos y geoquímicos. Revista de la Asociación Geológica Argentina 31, 260-278.

Rapela, C.W., 2000. The Sierras Pampeanas of Argentina: Paleozoic building of the Southem Proto-Andes. In: Cordani, U.G., Milani, E.J., ThomazFilho, A., Campos, D.A. (Eds.), Tectonic Evolution of South America. 31 International Geological Congress, pp. 381-387.

Rapela, C.W., Llambías, E.J., 1999. El magmatismo Gondwánico y los ciclos Fanerozoicos. In: Caminos, R., (Ed.) Geología Argentina, Subsecretaría de Minería de la Nación, SEGEMAR, Instituto de Geología y Recursos Minerales Anales 29, 373-376.

Rapela, C., Heaman, L., Mcnutt, R., 1982. Rb-Sr geochronology of granitoid rocks from the Pampean ranges, Argentina. Journal of Geology 90, 574-582.

Rapela, C.W., Toselli, A., Heaman, L., Saavadra, J., 1990. Granit plutonism of the Sierra Pampeanas: an inner cordilleran Paleozoic arc in the southern Andes. In: Kay, S.M., Rapela, C.W., (Eds.) Plutonism from Antarctica to Alaska. Geological Society of America, Special Paper 241, 77-90.

Rapela, C.W., Pankhurst, R.J., Kirschbaum, A., Baldo, E.G.A., 1991. Facies intrusivas de edad carbónica en el Batolito de Achala: Evidencia de una anatexis regional en las Sierras Pampeanas? 6 Congreso Geológico Chileno Actas, vol. 1, pp. 40-43.

Rapela, C.W., Coira, B., Toselli, A., Saavedra, J., 1992. The Lower Paleozoic Magmatism of Southwestern Gondwana and the evolution of Famatinian Orogene. International Geology Review 34, 1081-1142.

Rapela, C.W., Saavedra, J., Toselli, A., Pellitero, E., 1996. Eventos magmáticos fuertemente peraluminosos en las Sierras Pampeanas. Simposio Internacional 'Proto-Andean Margin of Gondwana', 13 Congreso Geológico Argentino Actas, vol. 5, pp. 337-354.

Rapela, C.W., Pankhurst, R.J., Casquet, C., Baldo, E., Saavedra, J., Galindo, C., Fanning, C.M., 1998a. The Pampean Orogeny of the southern proto-Andes: evidence for Cambrian continental collision in the Sierras de Córdoba. In: Pankhurst, R.J., Rapela, C.W., (Eds.) The Proto-Andean Margin of Gondwana, Geological Society of London, Special Publication 142, 181-217.

Rapela, C.W., Pankhurst, R.J., Casquet, C., Baldo, E., Saavedra, J., Galindo, C., 1998b. Early evolution of the proto-Andean margin of South America. Geology 26, 707-710.
Rapela, C.W., Casquet, C., Baldo, E., Dahlquist, J., Pankhurst, R.J., Galindo, C., Saavedra, J., 2001a. La Orogénesis del Paleozoico Inferior en el margen proto-andino de América del Sur, Sierras Pampeanas, Argentina. Journal of Iberian Geology 27, 23-41.

Rapela, C.W., Pankhurst, R.J., Baldo, E.G., Casquet, C., Galindo, C., Fanning, C.M., 2001. Ordovician metamorphism in the Sierras Pampeanas: new U$\mathrm{Pb}$ SHRIMP ages in central-east Valle Fértil and the Velasco batholith. III South American Symposium on Isotope Geology, Pucón, Chile. Actas SERNAGEOMIN, CD-ROM, pp. 616-619.

Rossi, J.N., Toselli, A.J., López, J., 1999. Deformación y metamorfismo en el NW de la Sierra de Velasco, La Rioja, Argentina. Zentralblatt fur Geologie und Paläontologie Teil I (Heft 7/8), 839-850 (Stuttgart).

Saavedra, J., Baldo, E., Pankhurst, R.J., Rapela, C.W., Murra, J., 1998. El granito Capilla del Monte (Sierras Pampeanas de Córdoba, Argentina): edad, geoquímica, génesis y especialización metalogénica. 10 Congreso Latinoamericano de Geología Actas, vol. 2, p. 372.

Scheepers, R., 2000. Granites of the Saldania mobile belt, south Africa: radioelements and $\mathrm{P}$ as discriminators applied to metallogeny. Journal of Geochemical Exploration 68, 69-86.

Sims, J.P., Ireland, T.R., Camacho, A., Lyons, P., Pieters, P.E., Skirrow, R.G., Stuart-Smith, P.G., 1998. U-Pb, Th-Pb and Ar-Ar geochronology from the southern Sierras Pampeanas, Argentina: implications for the Palaeozoic tectonic evolution of the western Gondwana margin. In: Pankhurst, R.J., Rapela, C.W., (Eds.) The Proto-Andean Margin of Gondwana, Geological Society of London, Special Publication 142, 259-281.

Toselli, G.A., Saavedra, J., del Valle Córdoba, G., Medina, M.E., 1991. Petrología y geoquímica de los granitos de la zona de Carrizal-Mazán, La Rioja y Catamarca. Asociación Geológica Argentina, Revista 46, 36-50.

Toselli, A.J., Rossi, J.N., Sardi, F., López, J., Báez, M.A., 2000. Caracterización Petrográfica y Geoquímica de Granitoides de la Sierra de Velasco, La Rioja, Argentina. Extended Abstracts. CD-ROM of the 17 Simposio sobre la geología de Latinoamérica. Profil 18, Institut für Geologie und Paläontologie der Universität Stuttgart, Germany.

Whalen, J.B., Currie, K.L., Chappell, B.W., 1987. A-type granites: geochemical characteristics, discrimination and petrogenesis. Contributions to Mineralogy and Petrology 95, 407-419.

Williams, I.S., 1998. U-Th-Pb Geochronology by ion microprobe. In: McKibben, M.A., Shanks III., W.C., Ridley, W.I., (Eds.) Applications of Microanalytical Techniques to Understanding Mineralizing Processes. Reviews in Economic Geology 7, 1-35. 